\title{
Effect of Deficit Irrigation and Reduced N Fertilization on Plant Growth, Root Morphology and Water Use Efficiency of Tomato Grown in Soilless Culture
}

\author{
Ikram Ullah ${ }^{1}\left(\mathbb{D}\right.$, , Hanping Mao ${ }^{1, *}$, Ghulam Rasool ${ }^{2} \mathbb{D}$, Hongyan Gao ${ }^{1}$, Qaiser Javed ${ }^{3}$, Abid Sarwar $^{4}(\mathbb{D}$ and \\ Muhammad Imran Khan ${ }^{5}$
}

\section{check for} updates

Citation: Ullah, I.; Mao, H.; Rasool, G.; Gao, H.; Javed, Q.; Sarwar, A.; Khan, M.I. Effect of Deficit Irrigation and Reduced N Fertilization on Plant Growth, Root Morphology and Water Use Efficiency of Tomato Grown in Soilless Culture. Agronomy 2021, 11, 228. https://doi.org/10.3390/ agronomy 11020228

Academic Editors: Ivan Francisco Garcia Tejero and Victor Hugo Durán-Zuazo

Received: 8 December 2020

Accepted: 22 January 2021

Published: 26 January 2021

Publisher's Note: MDPI stays neutral with regard to jurisdictional claims in published maps and institutional affiliations.

Copyright: (c) 2021 by the authors. Licensee MDPI, Basel, Switzerland This article is an open access article distributed under the terms and conditions of the Creative Commons Attribution (CC BY) license (https:// creativecommons.org/licenses/by/ $4.0 /)$
1 School of Agricultural Equipment Engineering, Jiangsu University, Zhenjiang 212013, China; ikramullah@ujs.edu.cn (I.U.); gaohy@ujs.edu.cn (H.G.)

2 College of Hydrology and Water Resources, Hohai University, Nanjing 210098, China; gr_uaf@yahoo.com

3 School of the Environment and Safety Engineering, Jiangsu University, Zhenjiang 212013, China; qjaved_uaf@yahoo.com

4 Department of Irrigation and Drainage, University of Agriculture, Faisalabad 38000, Pakistan; abid.sarwar@wsu.edu

5 Research Center of Fluid Machinery Engineering and Technology, Jiangsu University, Zhenjiang 212013, China; imrankhan7792@yahoo.com

* Correspondence: maohp@ujs.edu.cn; Tel.: +86-1351-169-5868

\begin{abstract}
This study was conducted to investigate the effects of various irrigation water (W) and nitrogen $(\mathrm{N})$ levels on growth, root-shoot morphology, yield, and irrigation water use efficiency of greenhouse tomatoes in spring-summer and fall-winter. The experiment consisted of three irrigation water levels (W: 100\% of crop evapotranspiration (ETc), 80\%, and 60\% of full irrigation) and three $\mathrm{N}$ application levels (N: $100 \%, 75 \%$, and $50 \%$ of the standard nitrogen concentration in Hoagland's solution treatments equivalent to $15,11.25,7.5 \mathrm{mM}$ ). All the growth parameters of tomato significantly decreased $(p<0.05)$ with the decrease in the amount of irrigation and nitrogen application. Results depicted that a slight decrease in irrigation and an increase in $\mathrm{N}$ supply improved average root diameter, total root length, and root surface area, while the interaction was observed non-significant at average diameter of roots. Compared to the control, $\mathrm{W}_{80} \mathrm{~N}_{100}$ was statistically non-significant in photosynthesis and stomatal conductance. The $\mathrm{W}_{80} \mathrm{~N}_{100}$ resulted in a yield decrease of $2.90 \%$ and $8.75 \%$ but increased irrigation water use efficiency (IWUE) by $21.40 \%$ and $14.06 \%$. Among interactions, the reduction in a single factor at $W_{80} \mathrm{~N}_{100}$ and $\mathrm{W}_{100} \mathrm{~N}_{75}$ compensated the growth and yield. Hence, $\mathrm{W}_{80} \mathrm{~N}_{100}$ was found to be optimal regarding yield and IWUE, with $80 \%$ of irrigation water and $15 \mathrm{mM}$ of $\mathrm{N}$ fertilization for soilless tomato production in greenhouses.
\end{abstract}

Keywords: deficit irrigation; hydroponics; nitrogen; root growth; tomato; water saving

\section{Introduction}

Tomato is not only one of the world's most popular vegetable crops in taste but also a rich source of antioxidant lycopene, vitamins, organic acids, and essential minerals to keep us healthy [1]. As the leading tomato producer, recent total production of tomato in China has reached 6.05 million tons per year according to the report of the Food and Agriculture Organization of the United Nations (FAO) [2]. The tomato growth area in solar greenhouses is increasing rapidly in China to utilize the land and limited water resources more efficiently. Greenhouse technology added remarkable profits to farmers' income with the ease in managing the growth conditions compared to the field. To produce fresh tomatoes, tomatoes grown in greenhouses need far less water and $\mathrm{N}$ per $\mathrm{kg}$ of fresh tomato production than under conventional management but still, there is a large community of farmers using a high amount of fertilizers and water with the aim to increase yield [3]. However, the increased supply of water and fertilizers does not increase yield 
proportionally. As nitrogen $(\mathrm{N})$ is a major constituent of fertilizers, the excessive nitrogen application may increase undesired plant leaf growth affecting the tomato yield instead. Therefore, it is imperative to optimize the amount of water and $\mathrm{N}$ supply for tomato production to maintain a balance among plant growth (root/shoot) and yield to enhance the water use efficiency (WUE).

Since water and $\mathrm{N}$ are intrinsically linked, suitable irrigation along with considerable inputs of nitrogen fertilizer is required to regulate plant physiology in results of plant water and nutrient uptake [4]. In an attempt to save water, deficit irrigation is a promising technique, and it increases WUE due to reduced transpiration caused by water stress. Some researchers have reported that deficit irrigation decreases tomato fruit yield $[5,6]$ within an acceptable range but increased tomato quality $[1,7,8]$.

Nitrogen is another important crop limiting factor for controlling physiological crop processes promoting plant growth and yield. Many studies reported that increased application of $\mathrm{N}$ improves plant water use efficiency, increasing leaf photosynthesis by promoting leaf and root development, and hence enhancing plant biomass production [9,10]. In contrast, excessive $\mathrm{N}$ application in tomato cultivation may result in high nitrate leaching, representing a high risk of nitrate pollution [3,7,11] and inhibiting crop transpiration [12,13]. Under limited nitrogen availability, root morphology plays an important role, which may increase root surface area or root elongation for nutrient acquisition. Such improvements may enhance the resource allocation to root development as a whole, leading to greater root-shoot ratios under nutrient-limited conditions [14]. This extensive root system promotes water uptake ability when the plant is susceptible to water stress [15]. However, further investigation on effects of reduced irrigation and nitrogen on root characteristics and yield of tomato grown in a soilless substrate is needed.

There are numerous studies about tomato yield, water use efficiency, and fruit quality responses to deficit irrigation [16,17] and nitrogen [18,19] individually. However, few studies were done on the effects of different amounts of irrigation water and nitrogen applications under soilless substrate on the shoot and root parameters. Therefore, it becomes imperative to employ appropriate strategies for the proper supply of nutrients with a decreased water amount to ensure proper root-shoot growth and enhance water use efficiency by saving water and nitrogen inputs. The aims of this research were to (i) explore the effects of various water and $\mathrm{N}$ levels on root-shoot morphology, (ii) determine yield and irrigation water use efficiency (IWUE), and (iii) study the relationship between photosynthetic parameters and water use efficiency under different $\mathrm{W}$ and $\mathrm{N}$ rates. The obtained results can recommend an optimal strategy for water and $\mathrm{N}$ management for greenhouse tomatoes.

\section{Materials and Methods}

\subsection{Site Description}

The pot experiments were conducted in two growing seasons from March to July (spring-summer, SS) and September to December (fall-winter, FW) in 2019 in a greenhouse located at Jiangsu University, Zhenjiang, PR China, $\left(32.20^{\circ} \mathrm{N}, 119.45^{\circ} \mathrm{E}\right)$. Average indoor greenhouse relative humidity and temperature were $70.85 \%, 22.76^{\circ} \mathrm{C}$, and $77.89 \%, 20.20{ }^{\circ} \mathrm{C}$, during growing seasons, respectively.

Tomato (Solanum lycopersicum L.) Hezuo 906 variety was used as crop material for this experiment. For both seasons (SS and FW), tomato seedlings were transplanted in pots on 1st March and 5th September, respectively. Plants were supported by a nylon cord vertically. Pruning was done to maintain the proper growth following the well-managed agronomic local practices. Plant density was maintained as 3 plants $\mathrm{m}^{-2}$. Pots with height of $25 \mathrm{~cm}$ and diameter of $19 \mathrm{~cm}$ were filled with coarse perlite substrate $(2-4 \mathrm{~mm})$ to the height of $22.5 \mathrm{~cm}$ from the bottom. Some physical properties of perlite include bulk density (BD) $0.098\left(\mathrm{~g} \cdot \mathrm{cm}^{-3}\right)$, effective pore space (EPS) $71.9 \%(v / v)$, and conventional container capacity (CCC) $49.3 \%(v / v)$. 


\subsection{Experiment Design and Method}

The experiment was composed of three irrigation levels and three $\mathrm{N}$ levels. Three levels of irrigation water were applied based on crop evapotranspiration (ETc) in the control treatment, i.e., $100 \%$ ETc $\left(\mathrm{W}_{100}\right), 80 \%$ of $\mathrm{W}_{100}\left(\mathrm{~W}_{80}\right)$, and $60 \%$ of $\mathrm{W}_{100}\left(\mathrm{~W}_{60}\right)$, and three levels of $\mathrm{N}$ concentration were applied as a fertilization based on percent of the $\mathrm{N}$ available in full strength Hoagland's solution, i.e., $100 \%\left(\mathrm{~N}_{100}\right), 75 \%\left(\mathrm{~N}_{75}\right)$, and $50 \%\left(\mathrm{~N}_{50}\right)$. The plants were watered with Hoagland nutrient solution, which was modified in order to obtain three different $\mathrm{N}$ doses, by means of total or partial substitution of $\mathrm{KNO}_{3}$ and $\mathrm{Ca}\left(\mathrm{NO}_{3}\right)_{2}$ by adding $\mathrm{CaCl}_{2}$ and $\mathrm{K}_{2} \mathrm{SO}_{4}$ if necessary, where the tap water with electrical conductivity (EC) of $0.003 \mathrm{dSm}^{-1}$ was used to prepare the nutrient solution. The measured EC of the full-strength Hoagland solution was $1.94 \mathrm{dSm}^{-1}$, whereas the EC for $\mathrm{N}_{75}$ and $\mathrm{N}_{50}$ were $1.69 \mathrm{dSm}^{-1}$ and $1.44 \mathrm{dSm}^{-1}$, respectively. The $\mathrm{pH}$ of the nutrient solution was maintained between 5.5 and 6.5 by adding $\mathrm{NaOH}$ or $\mathrm{HCl}$ as needed. The treatments consisted of the application of different doses of $\mathrm{N}(15,11.25,7.5 \mathrm{mM})$. The experimental plan produced nine treatments with three replicates in each treatment $(3 \times 3 \times 3)$, where each treatment consisted of 3 plants, as shown in Table 1. The randomized complete block design was used for the given set of pots in this experiment.

Table 1. The treatment detail of the experiment.

\begin{tabular}{cccc}
\hline \multirow{2}{*}{ Treatments } & \multicolumn{3}{c}{ Nitrogen (ppm) } \\
\cline { 2 - 4 } & $\mathbf{N}_{\mathbf{1 0 0}}$ & $\mathbf{N}_{\mathbf{7 5}}$ & $\mathbf{N}_{\mathbf{5 0}}$ \\
\hline $\mathrm{W}_{100}$ & $\mathrm{~W}_{100} \mathrm{~N}_{100}$ & $\mathrm{~W}_{100} \mathrm{~N}_{75}$ & $\mathrm{~W}_{100} \mathrm{~N}_{50}$ \\
$\mathrm{~W}_{80}$ & $\mathrm{~W}_{80} \mathrm{~N}_{100}$ & $\mathrm{~W}_{80} \mathrm{~N}_{75}$ & $\mathrm{~W}_{80} \mathrm{~N}_{50}$ \\
$\mathrm{~W}_{60}$ & $\mathrm{~W}_{60} \mathrm{~N}_{100}$ & $\mathrm{~W}_{60} \mathrm{~N}_{75}$ & $\mathrm{~W}_{60} \mathrm{~N}_{50}$ \\
\hline
\end{tabular}

Uniform irrigation was applied for the first 10 days after transplanting the seedlings for proper establishment. The water consumed by plants was calculated based on the substrate water balance method in the control treatment. The amount of irrigation was applied and recorded to replace the consumed water in the control treatment $\left(\mathrm{W}_{100} \mathrm{~N}_{100}\right)$ in each irrigation event using the following equation.

$$
E T c=I-L-\Delta S
$$

where $I$ is the total amount of irrigation water, $L$ is the water leached after irrigation, and $\Delta S$ is the difference between the amount of substrate water stored before harvesting and treatment initiation. Moreover, there was no runoff in this experiment; however, a tiny amount of water leached out after a few irrigation events.

\subsection{Measurements}

\subsubsection{Growth Measurements}

Plant growth is defined by morphological measurement that includes the stem diameter, plant height, and plant leaf area. Manual calculation of plant height from each treatment was performed using a measuring tape $( \pm 0.1 \mathrm{~mm}$ error). The height of each selected plant was taken from the base of the stem to the growing tip of the last leaf. Similarly, stem diameter of all plants was measured from each treatment using a Vernier caliper at the base of the stem. Leaf area was determined just before the final harvest. The area of pruned leaves during all growth stages was summed up and added to the measured leaf area at the time of harvest to get the total leaf area of the plant. The total leaf area of the tomato plants [7] was calculated based on study of Schwarz and Kläring [20].

$$
A_{L}=a L_{w}^{b}
$$




$$
T \cdot A_{L}=a \sum_{k=t i}^{t f} L_{w}^{b}
$$

where T. $A_{L}$ reflects the total leaf area of a plant, $L_{w}$ is leaf width, $a=0.2031$ and $b=1.6738$ are the constant of integration and allometry coefficient, respectively, $t i$ and $t f$ are time limits from the initial time (day) of transplanting to final harvesting. At the end of the maturation stage, tomato plants from each treatment were selected, and fruit-free plants were used to assess fresh and dry plant biomass. Upon drying in an oven for $24 \mathrm{~h}$ at $105^{\circ} \mathrm{C}$, dry biomass including earlier collected leaves by pruning was measured to obtain the total dry biomass of plant from each treatment.

\subsubsection{Root Morphology}

Root morphological traits such as average diameter $(\mathrm{AD}, \mathrm{mm})$, total root length (TRL, $\mathrm{cm})$, root surface area $\left(\mathrm{RSA}, \mathrm{cm}^{2}\right)$, and root volume $\left(\mathrm{RV}, \mathrm{cm}^{3}\right)$ were measured at the end of the harvesting. The substrate containing roots of tomato was taken out of the pot and immersed in water. The substrate clod was rinsed using pressurized tap water after an hour of immersion in water and live roots were removed after the substrate debris and dead roots flowed away with water. Live roots were spread evenly in a tray containing deionized water and scanned using a flatbed scanner (300 dpi). Root images were analyzed after scanning using WinRhizo image analysis software (Regent Instruments, Quebec, Canada) and the average diameter (AD) and total root length (TRL), root surface area (RSA) and root volume (RV) were calculated using this software.

\subsubsection{Photosynthesis Parameters/Leaf Gas Exchange}

In both seasons, photosynthesis (Pn) and stomatal conductance (gs) were determined at the fruiting stage, i.e., 57 days after transplantation (DAT) for SS, and 60 DAT in FW 2019, respectively. Pn and gs of the newly expanded leaves were measured from 9:00 to 11:00 in the morning using a Li-6400 portable photosynthesis system (Li-COR Biosciences Ltd., Cambridge, UK). The photosynthetic active radiation (PAR), temperature, and $\mathrm{CO}_{2}$ concentration during the measurements were $800 \mu \mathrm{mol} \mathrm{m}^{-2} \mathrm{~s}^{-1}, 28^{\circ} \mathrm{C}$, and $500 \mu \mathrm{mol} \mathrm{mol}{ }^{-1}$, respectively.

\subsubsection{Fruit Yield and Irrigation Water Use Efficiency}

Tomato fruits were weighed separately from the first harvest until the last harvest and the total yield of each treatment was calculated at the end of the experiment. The total water applied as irrigation was determined as the total sum of applied water in each irrigation event during the whole experiment. Irrigation water use efficiency (IWUE) is the performance of tomato yield to applied irrigation water and it was calculated as [21]:

$$
I W U E=\frac{Y}{W}
$$

where, $Y$ indicates yield (ton ha ${ }^{-1}$ ) and $W$ represents water applied as irrigation (mm).

\subsection{Data Analysis}

Analysis of variance was attained using Statistix 8.1 statistical software. For means comparisons, least significant difference (LSD) was applied at $p<0.05$ significance level.

\section{Results}

\subsection{Plant Growth Parameter}

Morphological traits such as plant height, stem diameter, and leaf area were used to represent plant growth. Both irrigation and $\mathrm{N}$ fertilization levels affected plant growth significantly, as shown in Table 2. When analyzed across the $\mathrm{N}$ fertilization, the plant height, stem diameter, and leaf area showed a significant decrease with the decrease in each irrigation level. Analysis across the irrigation levels showed that $\mathrm{N}_{100}$ and $\mathrm{N}_{75}$ plants 
had significantly higher stem diameter, plant height, and leaf area than did $\mathrm{N}_{50}$ plants. However, $\mathrm{N}_{100}$ and $\mathrm{N}_{75}$ had no significant difference with each other across irrigation levels in plant height.

Table 2. Effect of water (W) and $\mathrm{N}$ on stem diameter, plant height, and leaf area during spring-summer (SS) and fall-winter (FW) season.

\begin{tabular}{|c|c|c|c|c|c|c|}
\hline \multirow{2}{*}{ Treatments } & \multicolumn{2}{|c|}{ Stem Diameter (mm) } & \multicolumn{2}{|c|}{ Plant Height (cm) } & \multicolumn{2}{|c|}{ Leaf Area $\left(\mathrm{cm}^{2}\right)$} \\
\hline & SS & FW & SS & FW & SS & FW \\
\hline \multicolumn{7}{|l|}{ Irrigation } \\
\hline $\mathrm{W}_{100}$ & $11.29 \mathrm{a}$ & $9.90 \mathrm{a}$ & 130.88 a & $119.12 \mathrm{a}$ & $1496.5 \mathrm{a}$ & $1163.2 \mathrm{a}$ \\
\hline $\mathrm{W}_{80}$ & $9.61 \mathrm{~b}$ & $9.38 \mathrm{~b}$ & $112.57 \mathrm{~b}$ & $108.98 b$ & $1275.7 \mathrm{~b}$ & $1013.6 \mathrm{~b}$ \\
\hline $\mathrm{W}_{60}$ & $8.07 \mathrm{c}$ & $8.12 \mathrm{c}$ & $98.06 \mathrm{c}$ & $94.04 \mathrm{c}$ & $780.6 \mathrm{c}$ & $712.3 \mathrm{c}$ \\
\hline \multicolumn{7}{|l|}{ Fertilizer } \\
\hline $\mathrm{N}_{100}$ & $10.60 \mathrm{a}$ & $10.17 \mathrm{a}$ & $125.71 \mathrm{a}$ & 117.81 a & $1382.4 \mathrm{a}$ & $1064.5 \mathrm{a}$ \\
\hline $\mathrm{N}_{75}$ & $9.92 \mathrm{ab}$ & $10.11 \mathrm{a}$ & $111.11 \mathrm{ab}$ & $104.42 \mathrm{ab}$ & $1200.1 \mathrm{~b}$ & $954.9 \mathrm{~b}$ \\
\hline $\mathrm{N}_{50}$ & $8.74 \mathrm{c}$ & $8.11 \mathrm{c}$ & $104.68 \mathrm{c}$ & $99.91 \mathrm{c}$ & $970.1 \mathrm{c}$ & $869.7 \mathrm{c}$ \\
\hline \multicolumn{7}{|l|}{ Interaction } \\
\hline $\mathrm{W}_{100} \mathrm{~N}_{100}$ & $12.13 \mathrm{a}$ & $11.30 \mathrm{a}$ & $153.50 \mathrm{a}$ & $130.43 \mathrm{a}$ & $1897.8 \mathrm{a}$ & $1299.2 \mathrm{a}$ \\
\hline $\mathrm{W}_{100} \mathrm{~N}_{75}$ & $11.37 \mathrm{~b}$ & $9.53 c$ & $128.23 \mathrm{~b}$ & $118.60 \mathrm{~b}$ & $1561.9 \mathrm{~b}$ & $1160 \mathrm{~b}$ \\
\hline $\mathrm{W}_{100} \mathrm{~N}_{50}$ & 10.37 c & 8.86 de & $110.90 \mathrm{c}$ & $108.33 \mathrm{c}$ & $1029.7 \mathrm{f}$ & $1030.4 \mathrm{c}$ \\
\hline $\mathrm{W}_{80} \mathrm{~N}_{100}$ & $10.97 \mathrm{bc}$ & $10.27 \mathrm{~b}$ & $129.37 \mathrm{~b}$ & $120.70 \mathrm{~b}$ & $1432.6 \mathrm{c}$ & $1141.6 \mathrm{~b}$ \\
\hline $\mathrm{W}_{80} \mathrm{~N}_{75}$ & $9.37 \mathrm{~d}$ & $9.43 \mathrm{~cd}$ & $107.10 \mathrm{~d}$ & $105.17 \mathrm{~cd}$ & $1272.6 \mathrm{~d}$ & $1012.5 c$ \\
\hline $\mathrm{W}_{80} \mathrm{~N}_{50}$ & $8.50 \mathrm{e}$ & $8.40 \mathrm{e}$ & $101.23 \mathrm{ef}$ & $101.07 \mathrm{e}$ & $1121.8 \mathrm{e}$ & $886.8 \mathrm{~d}$ \\
\hline $\mathrm{W}_{50} \mathrm{~N}_{100}$ & $8.70 \mathrm{e}$ & $8.93 \mathrm{cde}$ & $94.27 \mathrm{~g}$ & $102.30 \mathrm{de}$ & $816.9 \mathrm{~g}$ & $752.8 \mathrm{e}$ \\
\hline $\mathrm{W}_{50} \mathrm{~N}_{75}$ & $8.13 \mathrm{e}$ & $8.36 \mathrm{e}$ & $98 \mathrm{f}^{\circ}$ & $89.50 \mathrm{f}$ & $766 \mathrm{~g}$ & $692.3 \mathrm{e}$ \\
\hline $\mathrm{W}_{50} \mathrm{~N}_{50}$ & $7.36 \mathrm{f}$ & $7.07 \mathrm{f}$ & $101.90 \mathrm{e}$ & $90.33 \mathrm{f}$ & $758.9 \mathrm{~g}$ & $691.7 \mathrm{e}$ \\
\hline \multicolumn{7}{|l|}{ ANOVA } \\
\hline W & $* * *$ & $* * *$ & $* * *$ & $* * *$ & $* * *$ & $* * *$ \\
\hline $\mathrm{N}$ & $* * *$ & $* * *$ & $* * *$ & $* * *$ & $* * *$ & $* * *$ \\
\hline $\mathrm{W} \times \mathrm{N}$ & NS & NS & $* * *$ & $* *$ & $* * *$ & $* *$ \\
\hline
\end{tabular}

The data presented in the table are the mean of three replicates. According to the Least significant difference (LSD) test, values with different letters within the same columns are significantly different at $p<0.05$. NS, ${ }^{* *}, * *$ are not significant, significant at $p \leq 0.01$, significant at $p \leq 0.001$, respectively.

Considering the interaction effect of irrigation and $\mathrm{N}$ fertilization, the treatment $\mathrm{W}_{100}$ $\mathrm{N}_{\text {I00 }}$ was significantly higher in stem diameter, plant height, and leaf area than other interaction levels during both growing seasons, which was one of the treatments with the largest irrigation amount with maximum nitrogen input. Among the interaction of irrigation and $\mathrm{N}$ fertilization, stem diameter remained non-significant during both growing seasons, however, the plant height and leaf area were significant at $p<0.05$ during SS, while these were significant at $p<0.01$ during the FW season.

Total fresh and dry plant biomass were determined to evaluate the effects of different irrigation and $\mathrm{N}$ fertilization on plant growth, and results are shown in Table 3 . Analysis across the $\mathrm{N}$ treatments, fresh plant biomass (PFM) and dry plant biomass (PDM) were decreased significantly, parallel with a decrease in irrigation level. Considering only $\mathrm{N}$ levels, $\mathrm{N}_{75}$ had no significant difference with $\mathrm{N}_{100}$ in dry plant biomass, while both were significantly higher than $\mathrm{N}_{50}$. At the interaction effect of irrigation and $\mathrm{N}$ fertilization $(\mathrm{W} \times \mathrm{N})$, the PFM and PDM showed significant differences during the SS and FW seasons. The obtained biomass results in this study are quite similar to results obtained by another study conducted on tomato growth by Rasool et al. [22]. 
Table 3. Effect of irrigation and fertilizer levels on plant fresh and dry biomass during spring-summer (SS) and fall-winter (FW) season.

\begin{tabular}{|c|c|c|c|c|}
\hline \multirow{2}{*}{ Treatments } & \multicolumn{2}{|c|}{ PFM (g.plant $\left.{ }^{-1}\right)$} & \multicolumn{2}{|c|}{ PDM (g.plant $\left.{ }^{-1}\right)$} \\
\hline & SS & FW & SS & FW \\
\hline \multicolumn{5}{|l|}{ Irrigation } \\
\hline $\mathrm{W}_{100}$ & $364.89 a$ & $345.78 \mathrm{a}$ & $115.26 \mathrm{a}$ & $109.11 \mathrm{a}$ \\
\hline $\mathrm{W}_{80}$ & $315.11 \mathrm{~b}$ & $305.33 \mathrm{~b}$ & $109.39 \mathrm{~b}$ & $105.33 \mathrm{~b}$ \\
\hline $\mathrm{W}_{60}$ & $254.89 \mathrm{c}$ & $247.67 \mathrm{c}$ & $83.78 \mathrm{c}$ & $85.96 \mathrm{c}$ \\
\hline \multicolumn{5}{|l|}{ Fertilizer } \\
\hline $\mathrm{N}_{100}$ & $357.44 \mathrm{a}$ & $315.44 \mathrm{a}$ & $106.14 \mathrm{a}$ & $102.08 \mathrm{a}$ \\
\hline $\mathrm{N}_{75}$ & $317.78 \mathrm{~b}$ & $294.44 \mathrm{~b}$ & $106.69 \mathrm{a}$ & $100.62 \mathrm{a}$ \\
\hline $\mathrm{N}_{50}$ & $259.67 c$ & $288.89 \mathrm{~b}$ & $95.59 \mathrm{~b}$ & $97.70 \mathrm{~b}$ \\
\hline \multicolumn{5}{|l|}{ Interaction } \\
\hline $\mathrm{W}_{100} \mathrm{~N}_{100}$ & $410.67 \mathrm{a}$ & $378.33 \mathrm{a}$ & $125.03 \mathrm{a}$ & $112.03 \mathrm{a}$ \\
\hline$W_{100} N_{75}$ & $382.00 \mathrm{~b}$ & $329.00 \mathrm{~b}$ & $118.23 \mathrm{~b}$ & 109.73 a \\
\hline $\mathrm{W}_{100} \mathrm{~N}_{50}$ & $302.00 \mathrm{e}$ & $330.00 \mathrm{~b}$ & $102.50 \mathrm{c}$ & $105.77 \mathrm{~b}$ \\
\hline $\mathrm{W}_{80} \mathrm{~N}_{100}$ & $362.67 c$ & $336.00 \mathrm{~b}$ & $106.33 \mathrm{c}$ & $105.57 \mathrm{~b}$ \\
\hline $\mathrm{W}_{80} \mathrm{~N}_{75}$ & $339.33 \mathrm{~d}$ & $299.33 \mathrm{c}$ & $118.97 \mathrm{~b}$ & $101.67 \mathrm{c}$ \\
\hline $\mathrm{W}_{80} \mathrm{~N}_{50}$ & $243.33 \mathrm{f}$ & $280.67 \mathrm{~cd}$ & $102.87 \mathrm{c}$ & $108.57 \mathrm{ab}$ \\
\hline$W_{50} N_{100}$ & $299.00 \mathrm{e}$ & $232.00 \mathrm{e}$ & $87.07 \mathrm{~d}$ & 81.77 e \\
\hline $\mathrm{W}_{50} \mathrm{~N}_{75}$ & $232.00 \mathrm{f}$ & $238.33 \mathrm{e}$ & $82.87 \mathrm{de}$ & $88.17 \mathrm{~d}$ \\
\hline $\mathrm{W}_{50} \mathrm{~N}_{50}$ & $233.67 \mathrm{f}$ & $272.67 \mathrm{~d}$ & $81.40 \mathrm{e}$ & $87.93 \mathrm{~d}$ \\
\hline \multicolumn{5}{|l|}{ ANOVA } \\
\hline W & $* * *$ & $* * *$ & $* * *$ & $* * *$ \\
\hline $\mathrm{N}$ & $* * *$ & $* * *$ & $* * *$ & $* * *$ \\
\hline $\mathrm{W} \times \mathrm{N}$ & $* * *$ & $* * *$ & $* * *$ & $* * *$ \\
\hline
\end{tabular}

PFM; fresh plant biomass, PDM; dry plant biomass. The data presented in the table are the mean of three replicates. According to the LSD test, values with different letters within the same columns are significantly different at $p<0.05 .{ }^{* * *}$ is significant at $p \leq 0.001$.

\subsection{Root Morphology}

Total root length, total root surface area, average diameter, and total root volume characteristics are described in Figures 1 and 2 under the results of irrigation and $\mathrm{N}$ fertilization experiments carried out during spring-summer and fall-winter.

Across the $\mathrm{N}$-application rate, the effect of irrigation was significant on root morphological traits (TRL, RSA, AD, and RV). The TRL, RSA, and RV were significantly higher in $\mathrm{W}_{80}$ when compared with full irrigation $\left(\mathrm{W}_{100}\right)$ and severe deficit $\left(\mathrm{W}_{60}\right)$, while $\mathrm{AD}$ had no significant difference between $W_{100}$ and $W_{80}$. Analysis across irrigation showed that $\mathrm{N}_{100}$ resulted in higher values of root traits among other $\mathrm{N}$ fertilization treatments. However, TRL, AD, and RV had no significant difference between $\mathrm{N}_{100}$ and $\mathrm{N}_{75}$, except RSA, which had a significant difference among all $\mathrm{N}$ treatments.

The interaction of irrigation and $\mathrm{N}$ fertilization $(\mathrm{W} \times \mathrm{N})$ was significant at TRL, RSA, and $\mathrm{RV}$, except for $\mathrm{AD}$ which gave a non-significant difference during both seasons. The interaction of $\mathrm{W}_{80} \mathrm{~N}_{100}$ gave highest TRL and RSA, and had a significant difference when compared with other interactive pairs of irrigation and N during SS and FW. Similarly, $R V$ was found almost the same in $W_{80} N_{100}$ and $W_{80} N_{75}$ with slightly higher values in $\mathrm{W}_{80} \mathrm{~N}_{75}$, but there was no significant difference between both treatments. 

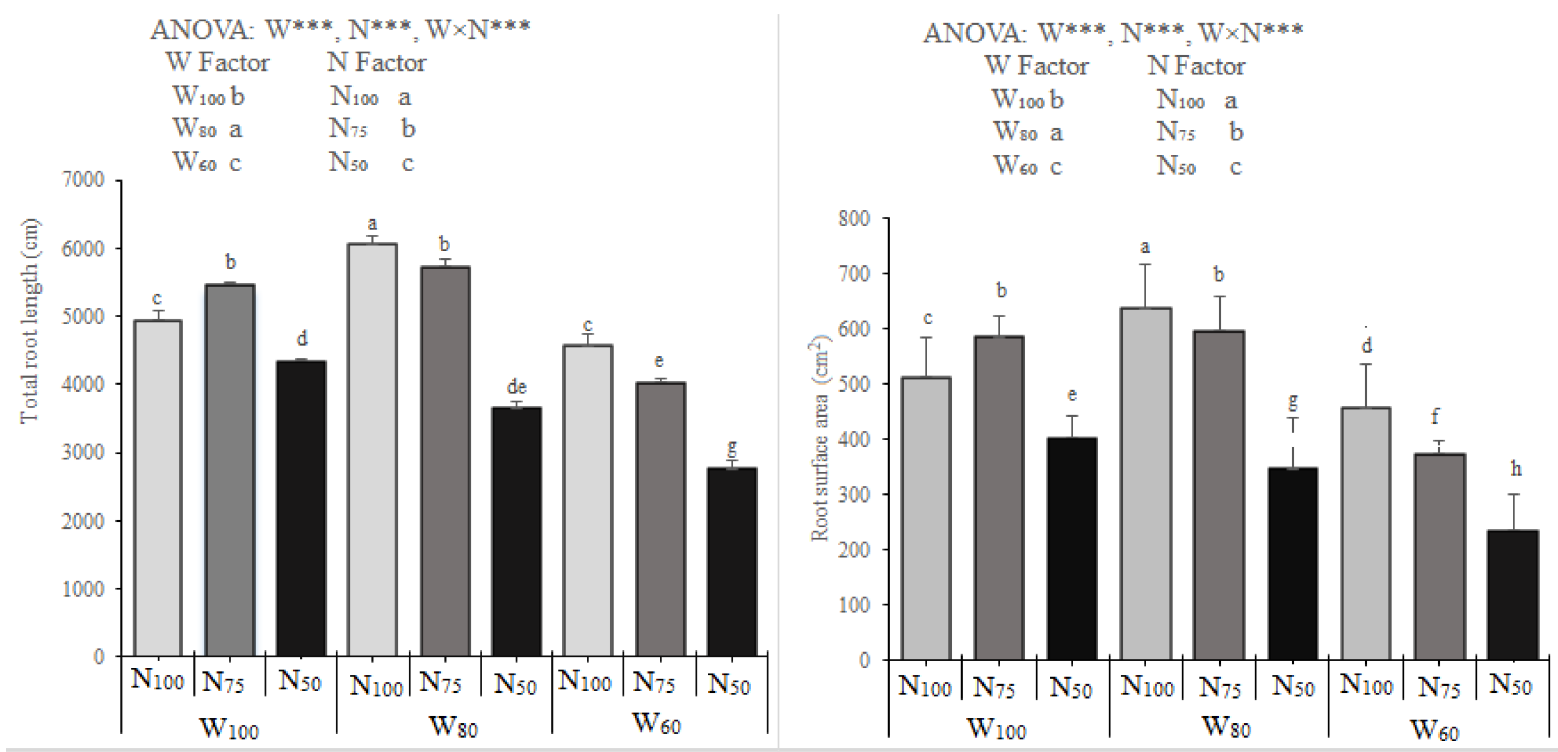

ANOVA: W***, $\mathrm{N}^{* * *}, \mathrm{~W} \times \mathrm{N}^{\mathrm{ns}}$

W Factor N Factor

$\mathrm{W}_{100 \mathrm{~b}} \quad \mathrm{~N}_{100}$ a

$\mathrm{W}_{80}$ a $\mathrm{N}_{75}$ b

$W_{60} \quad c \quad \mathrm{~N}_{50} \quad \mathrm{c}$
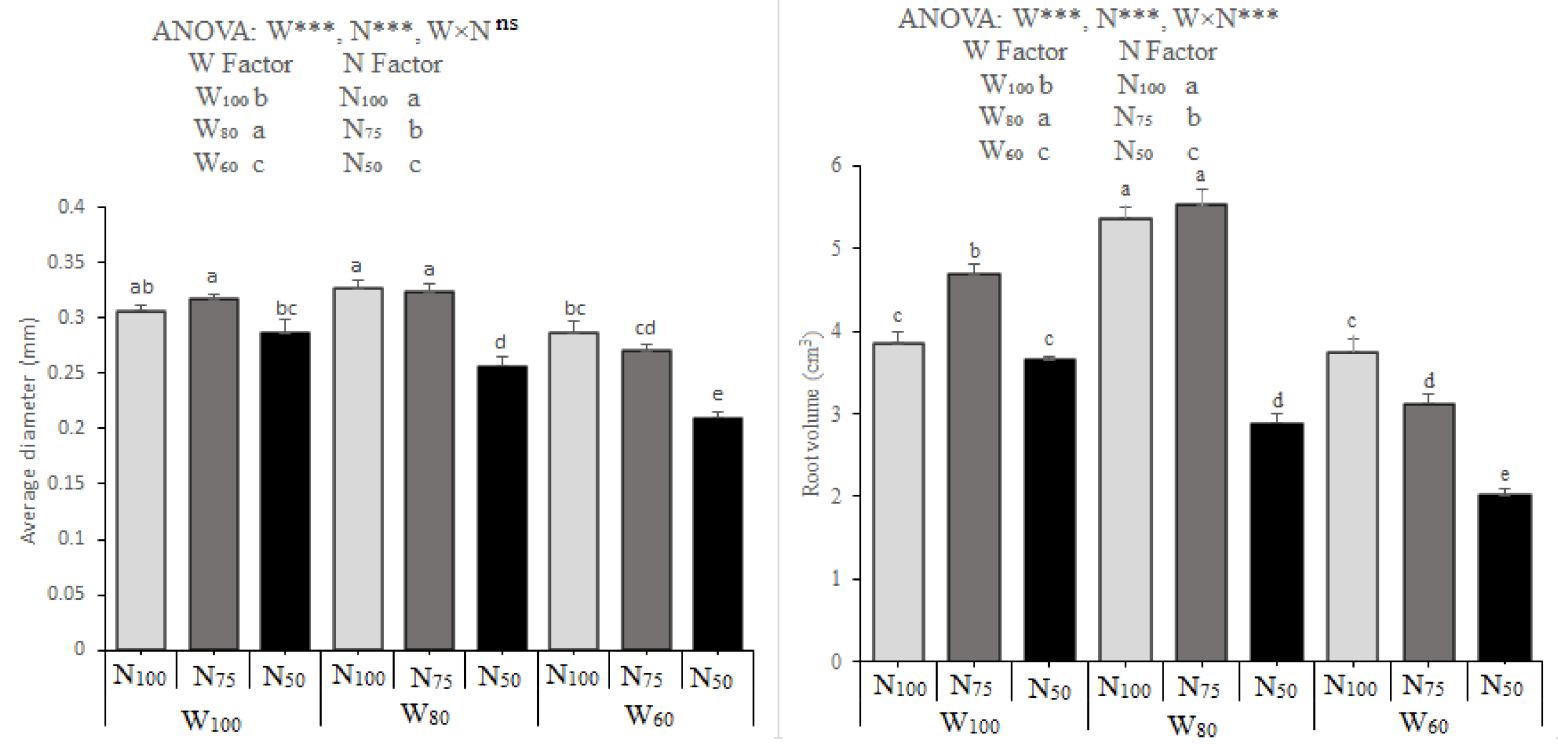

Figure 1. Effects of irrigation water $(\mathrm{W})$ and nitrogen fertilization $(\mathrm{N})$ on average diameter, total root length, root surface area, and root volume at the harvesting stage during spring-summer. Bars with different letters are significantly different at $p<0.05$ according to LSD test. ns, ${ }^{* * *}$ are not significant at $p>0.05$, significant at $p \leq 0.001$, respectively.

\subsection{Photosynthesis $(P n)$ and Stomatal Conductance $(g s)$}

Upon analysis across $\mathrm{N}$ fertilization, Pn and gs decreased significantly with each decreased level of irrigation. Pn and gs were found to be higher under full irrigation than those tomato plants under deficit water during both seasons, as shown in Table 4. Similarly, $\mathrm{Pn}$ and gs of tomato plants under high-N fertilization were higher than those of plants under low-N fertilization, irrespective of irrigation amount. Considering $\mathrm{N}$ fertilization overall, the pattern of Pn and gs were found to be parallel to irrigation except for gs at $\mathrm{N}_{100}$ and $\mathrm{N}_{75}$ during both seasons, where both treatments did not show a significant difference. Whatever the availability of $\mathrm{N}$ in the substrate, the increased availability of water in the rootzone has resulted in increased Pn. Compared to the control, the decrease in Pn was $7.72 \%$ and $36.77 \%$ in $\mathrm{W}_{80}$, and $11.09 \%$ and $40.79 \%$ in $\mathrm{W}_{60}$ during SS and FW, respectively. 


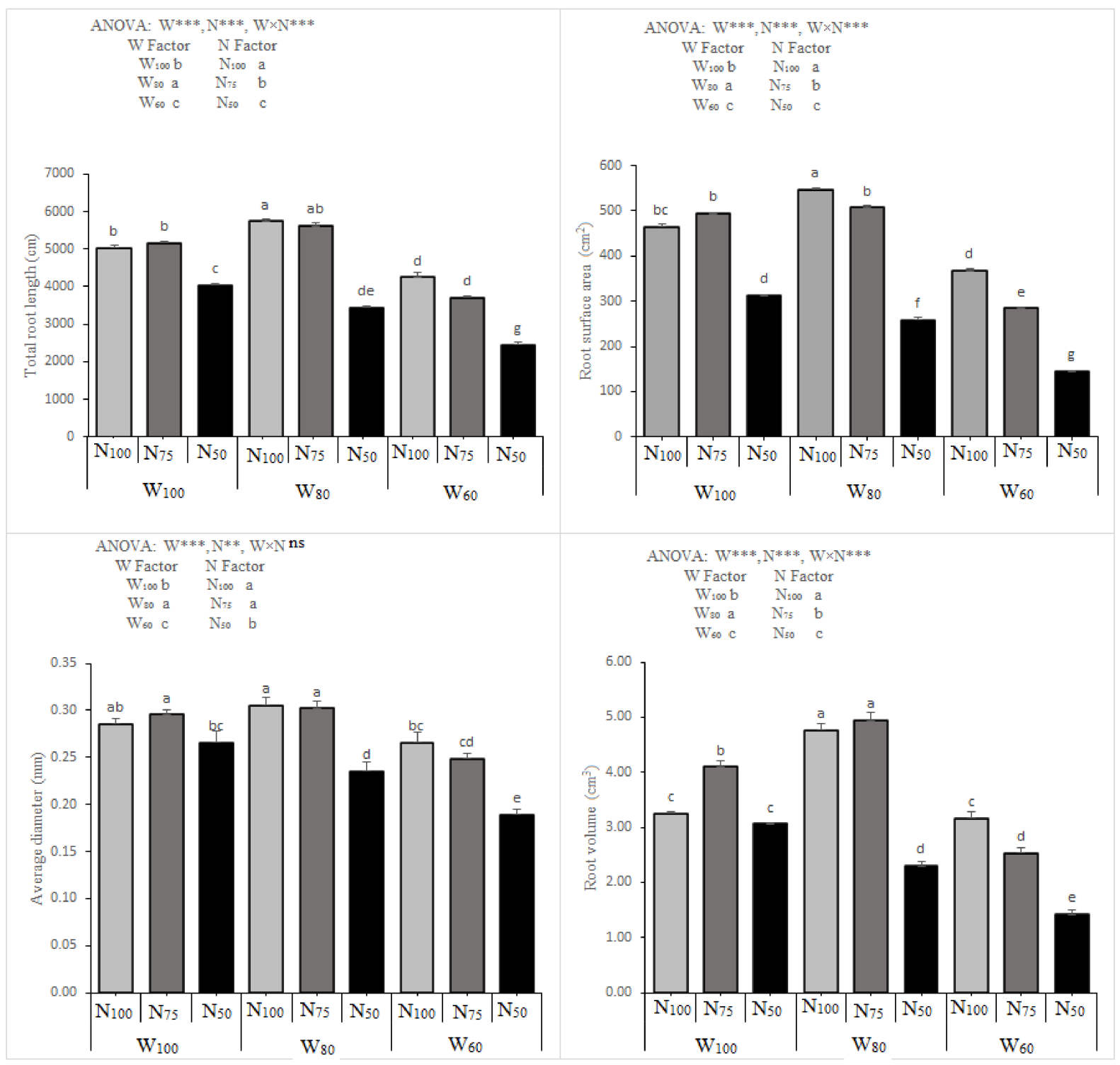

Figure 2. Effects of irrigation water $(\mathrm{W})$ and nitrogen fertilization $(\mathrm{N})$ on tomato total root length, root surface area, average diameter, and root volume at the harvesting stage during fall-winter. Bars with different letters are significantly dif-ferent at $p<0.05$ according to LSD test. ${ }^{* * *},{ }^{* *}$ indicate significance at $p<0.001$ and $p<0.01$, respectively, and ns indicates non-significance $(p>0.05)$.

Considering the interaction of irrigation and nitrogen $(\mathrm{W} \times \mathrm{N})$, the response of Pn and gs were recorded statistically significant to irrigation and $\mathrm{N}$ fertilization. Conversely, $\mathrm{W}_{80} \mathrm{~N}_{100}$ did not induce any loss in Pn during SS and FW, and gs during the FW season, and remain statistically non-significant when compared to treatment $W_{100} N_{100}$, as shown in Table 4 . The highest values of Pn and gs were found to be maximum under the interaction of the maximum level of water and nitrogen application. 
Table 4. Photosynthetic rate (Pn) and stomatal conductance (gs) across irrigation levels with different nitrogen concentration applied levels during the spring-summer (SS) and fall-winter (FW) season.

\begin{tabular}{|c|c|c|c|c|}
\hline \multirow{2}{*}{ Treatments } & \multicolumn{2}{|c|}{$\begin{array}{c}\text { Pn } \\
\left(\mu \mathrm{mol} \cdot\left(\mathrm{CO}_{2}\right) \cdot \mathrm{m}^{-2} \cdot \mathrm{s}^{-1}\right)\end{array}$} & \multicolumn{2}{|c|}{$\stackrel{\text { gs }}{\mathrm{mol} \cdot\left(\mathrm{H}_{2} \mathrm{O}\right) \cdot \mathrm{m}^{-2} \cdot \mathrm{s}^{-1}}$} \\
\hline & SS & FW & SS & FW \\
\hline \multicolumn{5}{|l|}{ Irrigation } \\
\hline $\mathrm{W}_{100}$ & $17.87 \mathrm{a}$ & $15.69 \mathrm{a}$ & $0.4533 \mathrm{a}$ & $0.2756 \mathrm{a}$ \\
\hline$W_{80}$ & $16.49 \mathrm{~b}$ & $13.95 \mathrm{~b}$ & $0.3262 \mathrm{~b}$ & $0.2345 \mathrm{~b}$ \\
\hline $\mathrm{W}_{60}$ & $11.30 \mathrm{c}$ & $9.29 c$ & $0.1943 c$ & $0.1234 \mathrm{c}$ \\
\hline \multicolumn{5}{|l|}{ Fertilizer } \\
\hline $\mathrm{N}_{100}$ & $16.45 \mathrm{a}$ & $14.71 \mathrm{a}$ & $0.3881 \mathrm{a}$ & $0.2419 a$ \\
\hline $\mathrm{N}_{75}$ & $16.25 \mathrm{~b}$ & $13.51 \mathrm{~b}$ & $0.3697 \mathrm{ab}$ & $0.2346 \mathrm{ab}$ \\
\hline $\mathrm{N}_{50}$ & $12.95 \mathrm{c}$ & $10.71 \mathrm{c}$ & 0.2492 c & $0.1570 \mathrm{c}$ \\
\hline \multicolumn{5}{|l|}{ Interaction } \\
\hline $\mathrm{W}_{100} \mathrm{~N}_{100}$ & $19.53 \mathrm{a}$ & $17.82 \mathrm{a}$ & $0.5178 \mathrm{a}$ & $0.3294 \mathrm{a}$ \\
\hline $\mathrm{W}_{100} \mathrm{~N}_{75}$ & $18.52 \mathrm{~b}$ & $17.00 \mathrm{~b}$ & $0.4419 c$ & $0.2779 c$ \\
\hline $\mathrm{W}_{100} \mathrm{~N}_{50}$ & $11.29 \mathrm{~g}$ & $13.05 \mathrm{c}$ & $0.2046 \mathrm{f}$ & $0.1184 \mathrm{~g}$ \\
\hline $\mathrm{W}_{80} \mathrm{~N}_{100}$ & $18.95 \mathrm{ab}$ & $17.76 \mathrm{ab}$ & $0.4839 \mathrm{~b}$ & $0.3138 \mathrm{ab}$ \\
\hline $\mathrm{W}_{80} \mathrm{~N}_{75}$ & $16.76 \mathrm{c}$ & $12.24 \mathrm{~d}$ & $0.2698 \mathrm{e}$ & $0.2557 \mathrm{~d}$ \\
\hline $\mathrm{W}_{80} \mathrm{~N}_{50}$ & $13.05 \mathrm{f}$ & $12.05 \mathrm{~d}$ & $0.2557 \mathrm{e}$ & $0.1344 \mathrm{f}$ \\
\hline $\mathrm{W}_{50} \mathrm{~N}_{100}$ & $15.12 \mathrm{~d}$ & $10.48 \mathrm{e}$ & $0.3582 \mathrm{~d}$ & $0.1837 \mathrm{e}$ \\
\hline $\mathrm{W}_{50} \mathrm{~N}_{75}$ & $14.18 \mathrm{e}$ & $9.54 \mathrm{f}$ & $0.2668 \mathrm{e}$ & $1699 \mathrm{e}$ \\
\hline $\mathrm{W}_{50} \mathrm{~N}_{50}$ & $9.54 \mathrm{~h}$ & $7.85 \mathrm{~g}$ & $0.1224 \mathrm{~g}$ & $0.1175 \mathrm{~g}$ \\
\hline \multicolumn{5}{|l|}{ ANOVA } \\
\hline $\mathrm{W}$ & $* * *$ & $* * *$ & $* * *$ & $* * *$ \\
\hline $\mathrm{N}$ & $* * *$ & $* * *$ & $* * *$ & $* * *$ \\
\hline $\mathrm{W} \times \mathrm{N}$ & $* * *$ & $* * *$ & $* * *$ & $* * *$ \\
\hline
\end{tabular}

The data presented in the table are the mean of three replicates. According to the LSD test, values with different letters within the same columns are significantly different at $p<0.05 .{ }^{* * *}$ is significant at $p \leq 0.001$.

\subsection{Yield and Irrigation Water Use Efficiency Response to Water and Nitrogen Levels}

As shown in Table 5, the tomato consumed a high water amount in the spring-summer season than in the fall-winter season. The highest tomato yield was observed in treatments with high water and $\mathrm{N}$ fertilization during the SS and FW seasons. The tomato yield decreased significantly $(p<0.05)$ with a decrease in irrigation amount, irrespective of $\mathrm{N}$ application. Similarly, when analyzed across the irrigation, the tomato yield increased with an increase in $\mathrm{N}$-application and reached maximum values at $\mathrm{N}_{100}(p<0.05)$.

The interaction effect of irrigation and $\mathrm{N}$ fertilization had a significant effect on yield $(p<0.05)$ in both seasons. Maximum yield was achieved at $\mathrm{W}_{100} \mathrm{~N}_{100}$. The treatments of interaction, $\mathrm{W}_{100} \mathrm{~N}_{75}$ and $\mathrm{W}_{80} \mathrm{~N}_{100}$, did not induce significant loss of yield when compared to $W_{100} N_{100}$ during SS, while $W_{100} N_{100}$ remained significantly higher than other interaction treatments.

Considering IWUE, irrespective of $\mathrm{N}$, the highest water use efficiency was recorded at an irrigation level of $W_{80}$ and $W_{60}$ in SS and FW, respectively. The highest IWUE was achieved in the highest $\mathrm{N}$ fertilization $\left(\mathrm{N}_{100}\right)$ when compared across the irrigation but there was no significant difference in the IWUE between $\mathrm{N}_{100}$ and $\mathrm{N}_{75}$ in FW.

During SS and FW, there was also a significant interaction between irrigation and $\mathrm{N}$-fertilizer for IWUE. The interaction of $\mathrm{W}_{80} \mathrm{~N} 1_{00}$ gave maximum irrigation water use efficiency during both seasons. Davies et al. [23] reported watering strategies to decrease the transpiration rate in plants, leading to a decrease in leaf area and stomatal openings, eventually improving IWUE. 
Table 5. Effect of $\mathrm{W}$ and $\mathrm{N}$ on water used, fruit yield, and irrigation water use efficiency.

\begin{tabular}{|c|c|c|c|c|c|c|}
\hline \multirow{2}{*}{ Treatments } & \multicolumn{2}{|c|}{ Irrigation Water (mm) } & \multicolumn{2}{|c|}{ Fruit Yield (ton $\left.\cdot h^{-1}\right)$} & \multicolumn{2}{|c|}{ Irrigation Water Use Efficiency } \\
\hline & SS & FW & SS & FW & SS & FW \\
\hline \multicolumn{7}{|l|}{ Irrigation } \\
\hline $\mathrm{W}_{100}$ & 245.98 & 222.51 & $92.23 \mathrm{a}$ & $81.03 \mathrm{a}$ & $37.50 \mathrm{c}$ & $36.41 \mathrm{c}$ \\
\hline $\mathrm{W}_{80}$ & 196.79 & 178.00 & $85.21 \mathrm{~b}$ & $72.48 \mathrm{~b}$ & $43.30 \mathrm{a}$ & $40.72 \mathrm{~b}$ \\
\hline $\mathrm{W}_{60}$ & 147.59 & 133.50 & $59.38 \mathrm{c}$ & $55.89 \mathrm{c}$ & $40.24 \mathrm{~b}$ & $41.86 \mathrm{a}$ \\
\hline \multicolumn{7}{|l|}{ Fertilizer } \\
\hline $\mathrm{N}_{100}$ & & & $85.95 \mathrm{a}$ & $76.17 \mathrm{a}$ & $43.60 \mathrm{a}$ & $42.99 \mathrm{a}$ \\
\hline $\mathrm{N}_{75}$ & & & $83.04 \mathrm{~b}$ & $72.49 \mathrm{~b}$ & $40.49 \mathrm{~b}$ & $41.15 \mathrm{ab}$ \\
\hline $\mathrm{N}_{50}$ & & & $67.84 \mathrm{c}$ & $60.76 \mathrm{c}$ & $34.94 \mathrm{c}$ & $34.86 \mathrm{c}$ \\
\hline \multicolumn{7}{|l|}{ Interaction } \\
\hline $\mathrm{W}_{100} \mathrm{~N}_{100}$ & 245.98 & 222.51 & $100.82 \mathrm{a}$ & $89.71 \mathrm{a}$ & $40.98 \mathrm{c}$ & $40.32 \mathrm{~d}$ \\
\hline $\mathrm{W}_{100} \mathrm{~N}_{75}$ & & & $99.42 \mathrm{a}$ & $86.75 \mathrm{~b}$ & $40.42 \mathrm{c}$ & 38.98 de \\
\hline $\mathrm{W}_{100} \mathrm{~N}_{50}$ & & & $76.47 \mathrm{c}$ & $66.62 \mathrm{e}$ & $31.09 \mathrm{e}$ & $29.94 \mathrm{~g}$ \\
\hline $\mathrm{W}_{80} \mathrm{~N}_{100}$ & 196.79 & 178.00 & $97.90 \mathrm{a}$ & $81.86 \mathrm{c}$ & $49.75 \mathrm{a}$ & $45.99 \mathrm{a}$ \\
\hline $\mathrm{W}_{80} \mathrm{~N}_{75}$ & & & $84.90 \mathrm{~b}$ & $71.52 \mathrm{~d}$ & $43.14 b$ & $40.18 \mathrm{~d}$ \\
\hline $\mathrm{W}_{80} \mathrm{~N}_{50}$ & & & $72.83 \mathrm{~d}$ & $64.07 \mathrm{f}$ & $37.01 \mathrm{~d}$ & $36.00 \mathrm{f}$ \\
\hline $\mathrm{W}_{50} \mathrm{~N}_{100}$ & 147.59 & 133.50 & $59.13 \mathrm{f}$ & $56.96 \mathrm{~g}$ & $40.07 \mathrm{c}$ & $42.66 \mathrm{c}$ \\
\hline $\mathrm{W}_{50} \mathrm{~N}_{75}$ & & & $64.80 \mathrm{e}$ & $59.13 \mathrm{~g}$ & $43.91 \mathrm{~b}$ & $44.29 \mathrm{~b}$ \\
\hline $\mathrm{W}_{50} \mathrm{~N}_{50}$ & & & $54.22 \mathrm{~g}$ & $51.57 \mathrm{~h}$ & $36.73 \mathrm{~d}$ & $38.63 \mathrm{e}$ \\
\hline \multicolumn{7}{|l|}{ ANOVA } \\
\hline W & $* * *$ & $* * *$ & $* * *$ & $* * *$ & $* * *$ & $* * *$ \\
\hline $\mathrm{N}$ & $* * *$ & $* * *$ & $* * *$ & $* * *$ & $* * *$ & $* * *$ \\
\hline $\mathrm{W} \times \mathrm{N}$ & $* * *$ & $* * *$ & $* * *$ & $* * *$ & $* * *$ & $* * *$ \\
\hline
\end{tabular}

The data presented in the table are the mean of three replicates. According to the LSD test, values with different letters within the same columns are significantly different at $p<0.05 . * *$ is significant at $p \leq 0.001$.

3.5. Relationship between Fruit Yield (FY), Photosynthesis (Pn), and Water Used (WU) under the Effect of Water and N Fertilization

The linear regression relationships of FY with water used, Pn, and gs during SS and FW are shown in Figure 3. Maximum linear regression $\left(R^{2}\right)$ among FY and Pn was observed as compared to water in use. For FY and Pn, the largest linear regression coefficients $\left(R^{2}\right)$ of 0.97 for SS and 0.98 for FW season were observed. The lowest values of $R^{2}$ were found to be at linear regression relationships of FY with WU. 
(a)

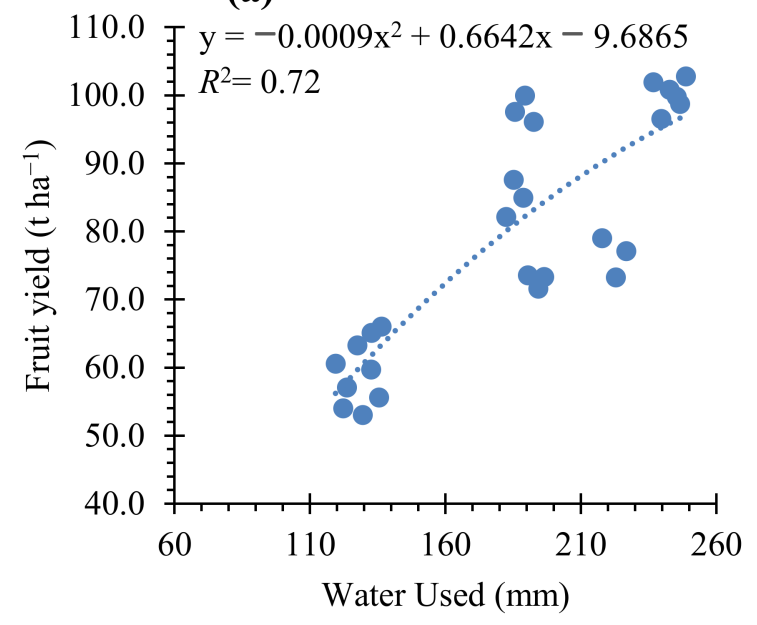

(b)

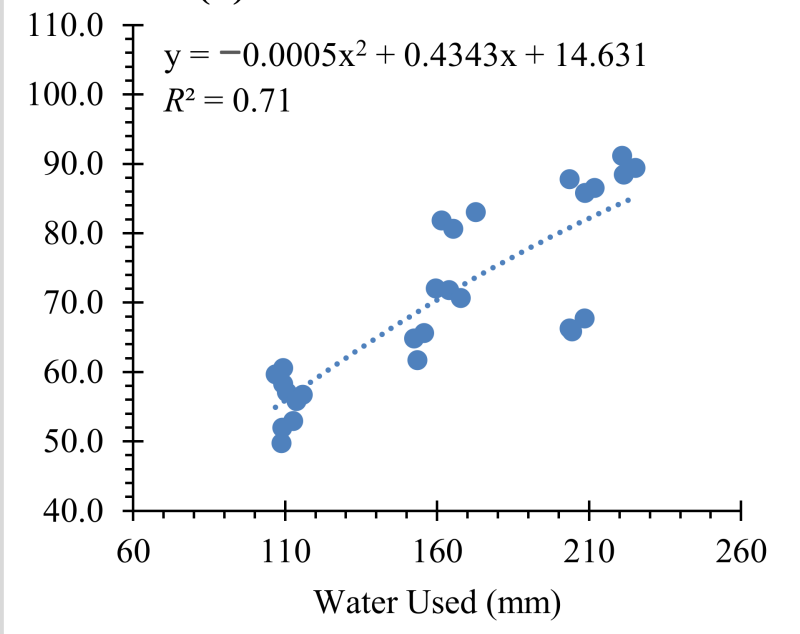

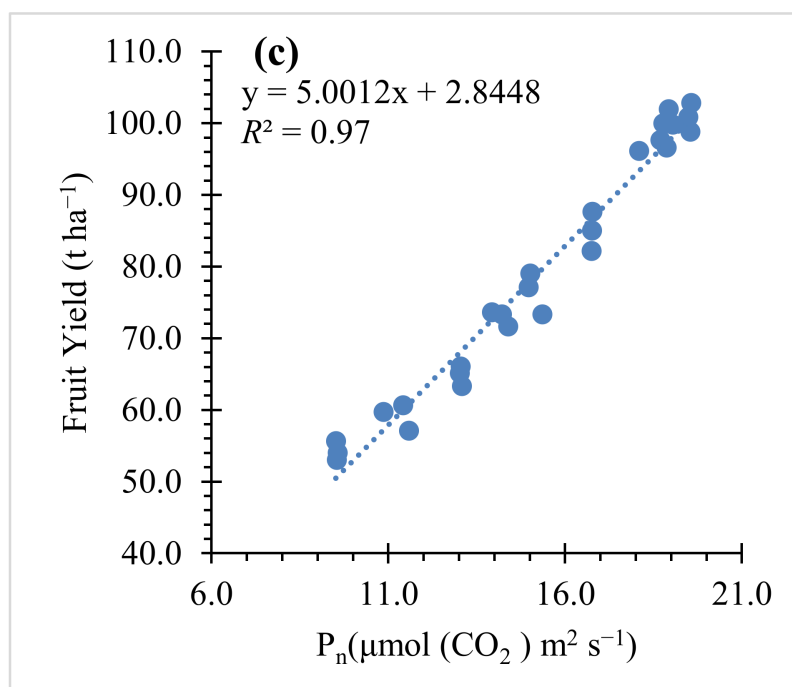
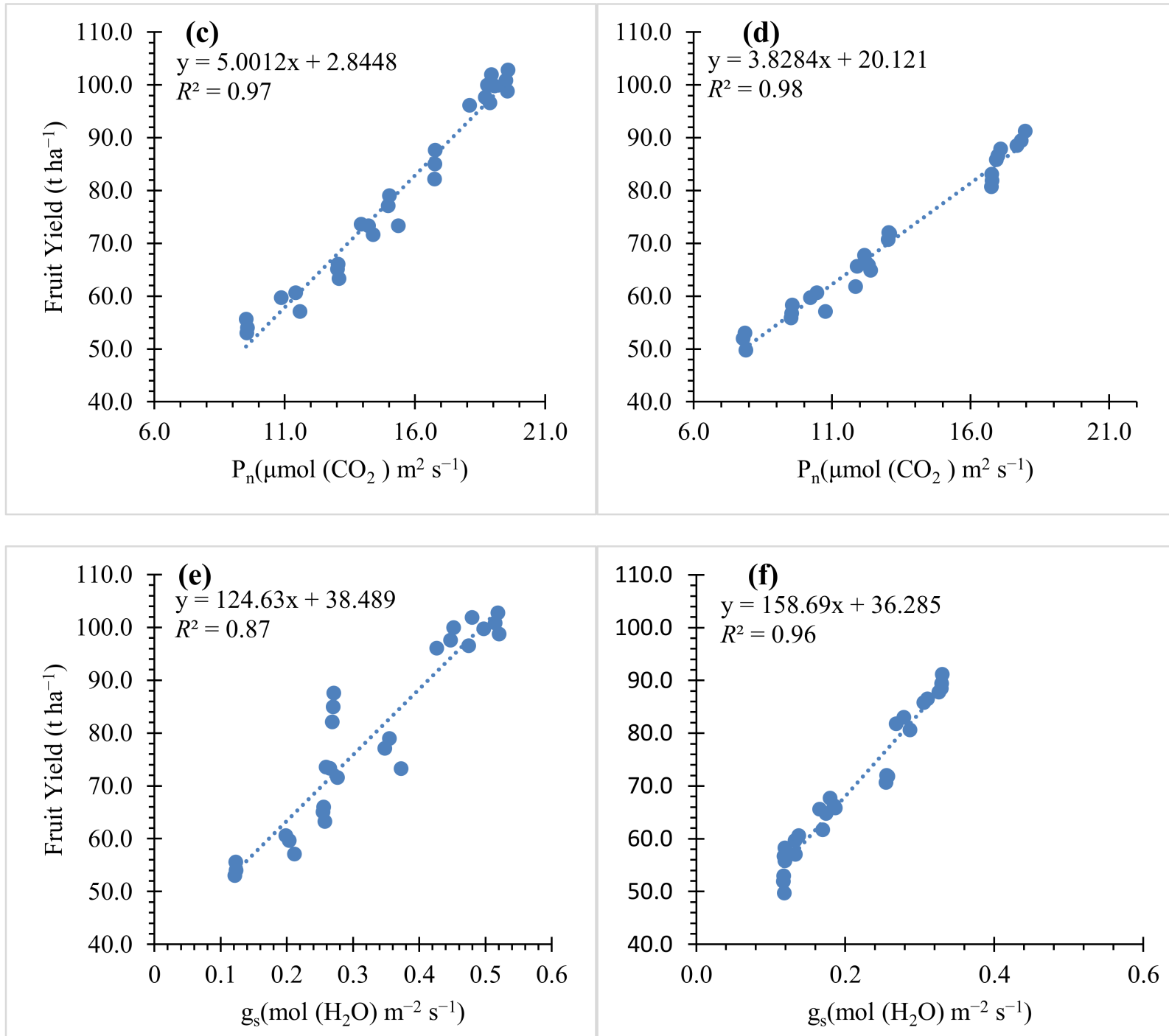

Figure 3. Regression models fitted for SS as (a) water used vs. fruit yield; (c) Pn vs. fruit yield; (e) gs vs. fruit yield, and for FW as (b) water used vs. fruit yield; (d) Pn vs. fruit yield; (f) gs vs. fruit yield. 


\section{Discussion}

Increasing growth and yield rely on optimal water and $\mathrm{N}$ application [24]. Water is essential for plant growth and its deficit would impact plant growth and production, depending on severity and duration of water deficit. It is well recognized that shoot and root growth have a direct influence on crop yield under an optimal growth environment, whereas their response can vary under a deficit water condition as well as nitrogen amount. Water and $\mathrm{N}$ fertilization demonstrated significant effects on overall plant growth and photosynthetic capacity of tomato. Fresh and dry plant biomass, leaf area, and plant height showed maximum values at treatments without shortage of irrigation and $\mathrm{N}$-application. Similar findings have been observed by Hou et al. [25] who found that stem diameter and plant height increased significantly with the increase in irrigation quantity at different growth stages of tomatoes. Rasool, Guo, Wang, Chen, and Ullah [22] stated comparable results and indicated that tomato biomass production was improved significantly due to the sufficient water supply during the crop maturity stage. Leaf area is an important growth parameter that serves for photosynthesis and gas exchange by allowing the PAR (photosynthetic active radiation) to fall on its surface area. The decreased leaf area could be due to stomatal closure and photosynthesis inhibition as a physiological response of plants to water and nitrogen deficit where flow of abscisic acid from roots to leaves tend to reduce stomatal aperture ultimately, causing reduction in leaf growth [26].

Being a primary organ, root characteristics are closely related to their water and nutrient absorption ability [27]. At the highest $\mathrm{N}$-application, the $\mathrm{W}_{80}$ (a water deficit treatment) gave the maximum root average diameter, length, surface area, and volume, which is evidence that $\mathrm{N}$-application enhances the root growth, and which can lead to an increased root biomass. This structural change in roots may have occurred due to reallocation of assimilates from shoot to root by plants under water stress, which resulted in decreased shoot growth and increased root system traits such as root length, root surface area, and root volume under reduced irrigation, as water is the main driver of resource allocation [28]. Moreover, N provided additive importance under water stress [29]. This could be because more photosynthetic products become conveyed to the root system under water stress, which improves root growth and nutrient and water absorption by enhancing root length, and finer root and deeper root spreading in the rootzone [30]. Changes in the root system to obtain more water and nutrients, the shoot system (reduced plant growth and leaf area), and physiology to trigger the underlying mechanisms are possible under deficit irrigation. However, the mechanisms through which the water deficit level of $W_{80}$ might possibly regulate root growth were not fully revealed by the present study. The increase in IWUE may be possible due to the decrease in stomatal conductance caused by the increased signal transduction network of guard cells [31]. Our study was also supported by Wang et al. [32], who stated that the interaction of medium deficit irrigation and N-nutrients show a significantly improved root surface area and total root volume, and could make a plant drought resistant without significant loss of yield. In addition, a better nutrient and water environment in the root zone can produce abscisic acid in the xylem by improving root to shoot signals, which can regulate vegetative growth and stomata switch [33,34].

Pn and gs are affected by water and $\mathrm{N}$-application [35]. In our study, Pn and gs showed a decline with the increase of water deficit and reducing $\mathrm{N}$-nutrition. Comparable results were also stated by Chen et al. [36], who revealed that an increase in water stress increased abscisic acid in roots, resulting in low photosynthesis and stomatal conductivity with its transportation to canopy causing stomatal closure. Del Amor et al. [37] also found the reduction in gs was due to a decrease in water availability in tomato plants. In our findings, an increase in water and $\mathrm{N}$ supply resulted in an increase in photosynthesis and a bigger biomass, which ultimately resulted in increased tomato fruit yield. Moreover, Garcia et al. [38] observed that the reduction in gs due to water stress is also influenced by nitrogen application quantity. They stated that applying nitrogen at $60 \%$ did not show a significant reduction in gs, which confirmed the findings of our study that $\mathrm{N}_{75} \operatorname{did}$ not 
decrease yield significantly compared to that measured at $\mathrm{N}_{100}$. Water stress reduces photosynthesis in tomato leaves, decreasing dry material accumulation and reducing tomato growth, which in turn decreases yield [39].

Both irrigation and nitrogen fertilization are essential factors for tomato growth, and they both influence yield and IWUE, however, nitrogen provided an additive importance to sustain the yield under certain ranges of deficit irrigation. Yield decrease was observed more with a decrease in irrigation rather than nitrogen. Patane and Cosentino [40] also reported that a yield decrease under deficit irrigation was observed nearly twice as low compared to full irrigation. The non-significant difference in yield at $W_{100}$ and $W_{80}$ under $\mathrm{N}_{100}$ is evidence that $\mathrm{N}$-application improves yield within a specific range of deficit irrigation [41], whereas further decreases in water or increases in nitrogen may lead to salt accumulation in the root zone, which could seriously affect the tomato yield [7].

Deficit watering has been described as a beneficial alternative strategy of water saving under an open field, as well as greenhouse cultivation in arid and semi-arid regions where water is the most limiting factor for crop cultivation. Traditionally, in situations of frequent water shortage and drought spells, it has been recommended to alleviate the adverse effects of water stress on crop yield and increase the efficiency of water efficiency [42]. Water use efficiency is a critical indicator at all scales, specifically during drought conditions when irrigation water is scarce. The highest irrigation water use efficiency was recorded at $\mathrm{W}_{80} \mathrm{~N}_{100}$ because of a non-significant difference in yield with the control, while water application was apparently reduced at $\mathrm{W}_{80}$ compared to $\mathrm{W}_{100}$. Considering $\mathrm{N}$-application, the highest water use efficiency was recorded at a higher nitrogen level. Among interactions, at the highest $\mathrm{N}, \mathrm{W}_{80}$ resulted in the highest water use efficiency and $\mathrm{N}$ application reduced the impact of reduced water on yield and hence resulted in high IWUE. Therefore, it is very important to optimize nitrogen and irrigation water supplies to improve crop yield, and water and nitrogen use efficiency in substrate cultivation. Earlier research has also determined that water use efficiency decreases with a rise in irrigation water amount [43]. The best irrigation rate under three different nitrogen levels for optimum WUE and IWUE in cucumber is $0.8 \mathrm{Ep}$ [44]. These results indicated that the reasonable application of nitrogen fertilizer should be emphasized. The highly efficient coordination of irrigation and nitrogen fertilization should also be stressed.

Along with deficit irrigation and reduced nitrogen application in greenhouses, WUE can be further improved by providing better climate control, $\mathrm{CO}_{2}$ dosage, and its integration with other possible techniques like growth-promoting substances, grafting, and with the use of anti-transpirants. Hence, interactive effects of such potential applications with deficit irrigation and nitrogen can be studied in future in broader perspectives.

\section{Conclusions}

Plants grown under deficit irrigation must be well-fertilized to serve as a compensation factor so as not to suffer from double stress. The increased tomato root length, surface area, and root volume in $\mathrm{W}_{80}$ provided more absorption surface for $\mathrm{N}$ uptake, which could be a reason to improve the biomass, yield, and water use efficiency, and provided evidence for better utilization of high $\mathrm{N}$ under moderate water stress. Due to limited availability of water, relatively small deficit irrigations are found applicable with an acceptable risk of yield decrease. In the current study, highest tomato yield was found at the highest irrigation and $\mathrm{N}$ application. There was no significant difference in yield upon reducing one of both inputs, i.e., $20 \%$ irrigation reduction from full irrigation or $25 \%$ reduction in $\mathrm{N}$ applied in control, but a simultaneous decrease of irrigation and nitrogen could not maintain the yield and IWUE at its highest level. These findings illustrate the importance for evaluation of impact on tomato yield under various levels of the interaction between nitrogen and water for proper management practices for sustainable agro-production. As there was no significant difference in yield among $\mathrm{W}_{100} \mathrm{~N}_{100}, \mathrm{~W}_{100} \mathrm{~N}_{75}$, and $\mathrm{W}_{80} \mathrm{~N}_{100}$, hence, considering optimal tradeoffs between yield, water saving, and water use efficiency, the $\mathrm{W}_{80} \mathrm{~N}_{100}$ could be adopted as an optimal strategy where $\mathrm{N}_{100}$ can be used as a source 
to mitigate the effects of deficit irrigation and reduce the risk of yield loss where scarcity of water availability exists. Besides a water and nutrient saving strategy, future works can consider the integration of deficit irrigation and reduced nitrogen with growth promoting organisms or with the use of anti-transpirants to sustain tomato yield and improve fruit nutritional quality.

Author Contributions: Conceptualization, I.U. and H.M.; methodology, I.U. and H.G.; software, G.R.; validation, A.S. and M.I.K.; formal analysis, I.U. and G.R.; investigation, Q.J.; writing-original draft preparation, I.U.; writing-review and editing, I.U., H.M., and G.R.; visualization, H.G.; supervision, H.M.; funding acquisition, H.M. All authors have read and agreed to the published version of the manuscript.

Funding: This research was funded by "National Key R\&D Projects, grant number 2018YFF0213600", "National Natural Science Foundation of China, grant number 61233006", "Natural Science Foundation of Jiangsu Province of China, grant number BK20180864", and "Jiangsu Synergy Innovation Center Program of Modern Agricultural Equipment and Technology, grant number 4091600028".

Institutional Review Board Statement: Not applicable.

Informed Consent Statement: Not applicable.

Data Availability Statement: Not applicable.

Conflicts of Interest: The authors declare no conflict of interest.

\section{References}

1. Wang, C.; Gu, F.; Chen, J.; Yang, H.; Jiang, J.; Du, T.; Zhang, J. Assessing the response of yield and comprehensive fruit quality of tomato grown in greenhouse to deficit irrigation and nitrogen application strategies. Agric. Water Manag. 2015, 161, 9-19. [CrossRef]

2. FAO. FAOSTAT (Food and Agriculture Organization of the United Nations). Available online: http://faostat3.fao.org/home/E (accessed on 6 February 2018).

3. Sun, Y.; Hu, K.; Fan, Z.; Wei, Y.; Lin, S.; Wang, J. Simulating the fate of nitrogen and optimizing water and nitrogen management of greenhouse tomato in North China using the EU-Rotate_N model. Agric. Water Manag. 2013, 128, 72-84. [CrossRef]

4. Zotarelli, L.; Scholberg, J.M.; Dukes, M.D.; Muñoz-Carpena, R.; Icerman, J. Tomato yield, biomass accumulation, root distribution and irrigation water use efficiency on a sandy soil, as affected by nitrogen rate and irrigation scheduling. Agric. Water Manag. 2009, 96, 23-34. [CrossRef]

5. Patanè, C.; Tringali, S.; Sortino, O. Effects of deficit irrigation on biomass, yield, water productivity and fruit quality of processing tomato under semi-arid Mediterranean climate conditions. Sci. Hortic. 2011, 129, 590-596. [CrossRef]

6. Shabbir, A.; Mao, H.; Ullah, I.; Buttar, N.A.; Ajmal, M.; Lakhiar, I.A. Effects of drip irrigation emitter density with various irrigation levels on physiological parameters, root, yield, and quality of cherry tomato. Agronomy 2020, 10, 1685. [CrossRef]

7. Ullah, I.; Hanping, M.; Chuan, Z.; Javed, Q.; Azeem, A. Optimization of irrigation and nutrient concentration based on economic returns, substrate salt accumulation and water use efficiency for tomato in greenhouse. Arch. Agron. Soil Sci. 2017, 63, 1748-1762. [CrossRef]

8. Ripoll, J.; Urban, L.; Staudt, M.; Lopez-Lauri, F.; Bidel, L.P.; Bertin, N. Water shortage and quality of fleshy fruits-Making the most of the unavoidable. J. Exp. Bot. 2014, 65, 4097-4117. [CrossRef]

9. Wang, L.; Palta, J.A.; Chen, W.; Chen, Y.; Deng, X. Nitrogen fertilization improved water-use efficiency of winter wheat through increasing water use during vegetative rather than grain filling. Agric. Water Manag. 2018, 197, 41-53. [CrossRef]

10. Hongyan, M.H.G.; Ni, J.; Gong, L.; Zhang, X. Effects of different fertilization on nutrient and growth of lettuce and models simulation. J. Drain. Irrig. Mach. Eng. 2020, 38, 1264-1269.

11. Rasool, G.; Guo, X.; Wang, Z.; Ali, M.U.; Chen, S.; Zhang, S.; Wu, Q.; Ullah, M.S. Coupling fertigation and buried straw layer improves fertilizer use efficiency, fruit yield, and quality of greenhouse tomato. Agric. Water Manag. 2020, 239, 106239. [CrossRef]

12. Matimati, I.; Verboom, G.A.; Cramer, M.D. Nitrogen regulation of transpiration controls mass-flow acquisition of nutrients. J. Exp. Bot. 2014, 65, 159-168. [CrossRef]

13. Hanping, M.; Ullah, I.; Jiheng, N.; Javed, Q.; Azeem, A. Estimating tomato water consumption by sap flow measurement in response to water stress under greenhouse conditions. J. Plant Interact. 2017, 12, 402-413. [CrossRef]

14. López-Bucio, J.; Cruz-Ramirez, A.; Herrera-Estrella, L. The role of nutrient availability in regulating root architecture. Curr. Opin. Plant Biol. 2003, 6, 280-287. [CrossRef]

15. Ding, L.; Lu, Z.; Gao, L.; Guo, S.; Shen, Q. Is Nitrogen a Key Determinant of Water Transport and Photosynthesis in Higher Plants Upon Drought Stress? Front. Plant Sci. 2018, 9, 1143. [CrossRef]

16. Hooshmand, M.; Albaji, M.; Ansari, N.A.Z. The effect of deficit irrigation on yield and yield components of greenhouse tomato (Solanum lycopersicum) in hydroponic culture in Ahvaz region, Iran. Sci. Hortic. 2019, 254, 84-90. [CrossRef] 
17. Zhang, H.; Xiong, Y.; Huang, G.; Xu, X.; Huang, Q. Effects of water stress on processing tomatoes yield, quality and water use efficiency with plastic mulched drip irrigation in sandy soil of the Hetao Irrigation District. Agric. Water Manag. 2017, 179, 205-214. [CrossRef]

18. Truffault, V.; Ristorto, M.; Brajeul, E.; Vercambre, G.; Gautier, H. To stop nitrogen overdose in soilless tomato crop: A way to promote fruit quality without affecting fruit yield. Agronomy 2019, 9, 80. [CrossRef]

19. Rosa-Rodríguez, R.D.l.; Lara-Herrera, A.; Trejo-Téllez, L.I.; Padilla-Bernal, L.E.; Solis-Sánchez, L.O.; Ortiz-Rodríguez, J.M. Water and fertilizers use efficiency in two hydroponic systems for tomato production. Hortic. Bras. 2020, 38, 47-52. [CrossRef]

20. Schwarz, D.; Kläring, H.-P. Allometry to estimate leaf area of tomato. J. Plant Nutr. 2001, 24, 1291-1309. [CrossRef]

21. Yang, H.; Cao, H.X.; Hao, X.M.; Guo, L.J.; Li, H.Z.; Wu, X.Y. Evaluation of tomato fruit quality response to water and nitrogen management under alternate partial root-zone irrigation. Int. J. Agric. Biol. Eng. 2017, 10, 85-94. [CrossRef]

22. Rasool, G.; Guo, X.; Wang, Z.; Chen, S.; Ullah, I. The interactive responses of fertigation levels under buried straw layer on growth, physiological traits and fruit yield in tomato plant. J. Plant Interact. 2019, 14, 552-563. [CrossRef]

23. Davies, W.J.; Wilkinson, S.; Loveys, B. Stomatal control by chemical signalling and the exploitation of this mechanism to increase water use efficiency in agriculture. New Phytol. 2002, 153, 449-460. [CrossRef]

24. Liu, W.; Wang, J.; Wang, C.; Ma, G.; Wei, Q.; Lu, H.; Xie, Y.; Ma, D.; Kang, G. Root growth, water and nitrogen use efficiencies in winter wheat under different irrigation and nitrogen regimes in North China Plain. Front. Plant Sci. 2018, 9, 1798. [CrossRef]

25. Hou, M.; Zhu, L.; Jin, Q. Surface drainage and mulching drip-irrigated tomatoes reduces soil salinity and improves fruit yield. PLoS ONE 2016, 11, e0154799. [CrossRef]

26. Badr, M.; El-Tohamy, W.; Hussein, S.; Gruda, N. Tomato yield, physiological response, water and nitrogen use efficiency under deficit and partial root zone drying irrigation in an arid region. J. Appl. Bot. Food Qual. 2018, 91, 332-340.

27. Ristova, D.; Busch, W. Natural variation of root traits: From development to nutrient uptake. Plant Physiol. 2014, 166, 518-527. [CrossRef]

28. Khapte, P.; Kumar, P.; Burman, U.; Kumar, P. Deficit irrigation in tomato: Agronomical and physio-biochemical implications. Sci. Hortic. 2019, 248, 256-264. [CrossRef]

29. Basal, O.; Szabó, A. The Combined Effect of Drought Stress and Nitrogen Fertilization on Soybean. Agronomy 2020, $10,384$. [CrossRef]

30. Sharp, R.E.; Poroyko, V.; Hejlek, L.G.; Spollen, W.G.; Springer, G.K.; Bohnert, H.J.; Nguyen, H.T. Root growth maintenance during water deficits: Physiology to functional genomics. J. Exp. Bot. 2004, 55, 2343-2351. [CrossRef]

31. Schroeder, J.I.; Kwak, J.M.; Allen, G.J. Guard cell abscisic acid signalling and engineering drought hardiness in plants. Nature 2001, 410, 327-330. [CrossRef]

32. Wang, Y.; Zhang, X.; Chen, J.; Chen, A.; Wang, L.; Guo, X.; Niu, Y.; Liu, S.; Mi, G.; Gao, Q. Reducing basal nitrogen rate to improve maize seedling growth, water and nitrogen use efficiencies under drought stress by optimizing root morphology and distribution. Agric. Water Manag. 2019, 212, 328-337. [CrossRef]

33. Sarker, K.K.; Akanda, M.; Biswas, S.; Roy, D.; Khatun, A.; Goffar, M. Field performance of alternate wetting and drying furrow irrigation on tomato crop growth, yield, water use efficiency, quality and profitability. J. Integr. Agric. 2016, 15, $2380-2392$. [CrossRef]

34. Chai, Q.; Gan, Y.; Zhao, C.; Xu, H.-L.; Waskom, R.M.; Niu, Y.; Siddique, K.H. Regulated deficit irrigation for crop production under drought stress. A review. Agron. Sustain. Dev. 2016, 36, 3. [CrossRef]

35. Mofokeng, M.; Steyn, J.; Du Plooy, C.; Prinsloo, G.; Araya, H. Growth of Pelargonium sidoides DC. in response to water and nitrogen level. S. Afr. J. Bot. 2015, 100, 183-189. [CrossRef]

36. Chen, J.; Kang, S.; Du, T.; Guo, P.; Qiu, R.; Chen, R.; Gu, F. Modeling relations of tomato yield and fruit quality with water deficit at different growth stages under greenhouse condition. Agric. Water Manag. 2014, 146, 131-148. [CrossRef]

37. Del Amor, F.M.; Ruiz-Sánchez, M.C.; Martínez, V.; Cerdá, A. Gas exchange, water relations, and Ion concentrations of salt-stressed tomato and melon plants. J. Plant Nutr. 2000, 23, 1315-1325. [CrossRef]

38. Garcia, A.; Marcelis, L.; García-Sánchez, F.; Nicolas, N.; Martínez, V. Moderate water stress affects tomato leaf water relations in dependence on the nitrogen supply. Biol. Plant. 2007, 51,707-712. [CrossRef]

39. Li, Y.; Sun, Y.; Liao, S.; Zou, G.; Zhao, T.; Chen, Y.; Yang, J.; Zhang, L. Effects of two slow-release nitrogen fertilizers and irrigation on yield, quality, and water-fertilizer productivity of greenhouse tomato. Agric. Water Manag. 2017, 186, 139-146. [CrossRef]

40. Patanè, C.; Cosentino, S. Effects of soil water deficit on yield and quality of processing tomato under a Mediterranean climate. Agric. Water Manag. 2010, 97, 131-138. [CrossRef]

41. Gebremariam, M.; Tesfay, T. Optimizing Irrigation Water and N Levels for Higher Yield and Reduced Blossom End Rot Incidence on Tomato. Int. J. Agron. 2019, 2019, 1-10. [CrossRef]

42. Geerts, S.; Raes, D. Deficit irrigation as an on-farm strategy to maximize crop water productivity in dry areas. Agric. Water Manag. 2009, 96, 1275-1284. [CrossRef]

43. Chen, S.; Zhou, Z.-J.; Andersen, M.N.; Hu, T.-T. Tomato yield and water use efficiency-Coupling effects between growth stage specific soil water deficits. Acta Agric. Scand. Sect. B Soil Plant Sci. 2015, 65, 460-469. [CrossRef]

44. Zhang, H.-X.; Chi, D.-C.; Qun, W.; Jun, F.; Fang, X.-Y. Yield and quality response of cucumber to irrigation and nitrogen fertilization under subsurface drip irrigation in solar greenhouse. Agric. Sci. China 2011, 10, 921-930. [CrossRef] 